\title{
Formulation, Development and Evaluation of Nano Ethosomal Gel of Tramadol Hydrochloride
}

\section{Om Shelke ${ }^{1 *}$ and Amol Kulkarni ${ }^{2}$}

${ }^{1}$ Faculty of Pharmacy, Pacific Academy of Higher Education and Research, Udaipur, Rajasthan, India

${ }^{2}$ Dattakala College of Pharmacy, Bhigwan, Maharashtra, India

\begin{abstract}
Topical administration of drugrs is better for local action and the efficiency of the topically administered drug is increased with Liposome, proliposomes and ethosomes. Tramadol $\mathrm{HCl}$ has used the local anaesthetic. Ethosomes were formulated using soya lecithin, cholesterol, ethanol and purified water using ultra shear homogenizer. Ethosomes were evaluated for vesicle size, shape, optical microscopy and in-vitro release study. FS05 and FC05 have better drug release profile than the other formulation. The ethosomes were entrapped in gel matrix of carbopol 980 in different concentration $0.75 \%, 1.00 \%, 1.25 \%$ and $1.50 \% \mathrm{w} / \mathrm{w}$. The formulated gel formulation were evaluated with parameter drug content, $\mathrm{pH}$, viscosity, spreadability, in-vitro release test, and ex-vivo study. The formulation FS05 $\mathrm{C03}$ and FC05 C03 have better in-vitro and ex-vivo drug release profile which contains Carbopol 980 concentration $1.25 \% \mathrm{w} / \mathrm{w}$. Both the formulation FS05 $\mathrm{C03}$ and FC05 $\mathrm{C0} 3$ were stable for 3 Months at room temperature and accelerated storage condition. The $3 \mathrm{M}$ stability sample of $\mathrm{FS} 05 \mathrm{C} 03$ has maintained the drug release profile but the drug release profile of formulation FC05 C03 has dropped significantly.
\end{abstract}

Keywords: Tramadol hydrochloride; Ethosomes; Liposomes; Gel formulation

\section{Introduction}

Ethosomes are innovative nanovesicles containing the drug in a matrix of lipids, ethanol and water. The ethosomes are soft and a highly flexible vesicle efficiently penetrates through the skin and increases the drug delivery of drug molecules. Ethosomes are elastic vesicles made up of Phospholipids containing $20-45 \%$ ethanol. Ethanol also acts as a penetration enhancer by dissolving the skin lipids. The ethosomes overcomes the disadvantages of Liposomes and proliposomes such as less stability, scalability issues, leakage of drugs, fusion of vesicles and breaking of vesicles. Ethanol is a well-known permeation enhancer. Ethosomes are highly flexible which permits the elastic vesicles to squeeze themselves among the skin pores. Ethanol gives the net negative charge on the surface of ethosome vesicles due to which aggregation is avoided because of electrostatic repulsion. Ethosomes are much more stable than the Liposomes and proliposomes. Topically administered ethosomes increases the residence time of the drug molecule in the different layers of skin such as stratum corneum, epidermis and reduces the systemic absorption. Because of all these properties, ethosomes get easily permeated in the deeper layer of skin and circulation. Ethanol in deeper layers of skin leads to disruption of the skin which increases the lipid fluidity that allows enhanced permeation of drug molecule through the skin. Ethosomes fuses with the skin lipids to release the drug into the deeper layers of skin [1-4].

Tramadol $\mathrm{HCl}$ is an opioid analgesic which is used in the treatment of severe and chronic pain. Tramadol $\mathrm{HCl}$ is prescribed 3-4 times a day. The frequent dosing of Tramadol $\mathrm{HCl}$ leads to the increased incidence of side effects, non-compliances and development of tolerance especially in long-term used like osteoarthritis, arthritis, post-surgical pains etc. So, to mitigate the disadvantages associated with oral therapy, topical ethosomes to increase the better penetration Tramadol $\mathrm{HCl}[5,6]$.

\section{Material and Methods}

\section{Material}

Tramadol HCl (Glenmark), Soya Lecithin (Lipoids), Cholesterol (Qualigens), Ethanol (Rankem), Propylene glycol (BASF). Rests of the reagents are used of Analytical reagent (AR) grade.

\section{Method}

\section{Preparation of ethosomes:}

Step 1: Solution A: Soya lecithin or Cholesterol were added in ethanol under stirring and continue stirring untill it dissolves completely.

Step 2: Solution B: Tramadol $\mathrm{HCl}$ is added in of the remaining quantity of ethanol under stirring at room temperature and stirring is continued at room temperature untill it forms the clear solution.

Step 3: Add Solution A to Solution B under ultra-shear homogenization and continue ultra-shear homogenization at speed $6000 \mathrm{rpm}$ for $30 \mathrm{~min}$.

Step 4: Add purified water under ultra-shear homogenization drop wise in the centre of the container. The dispersion is further homogenized for $15 \mathrm{~min}$ at room temperature with homogenization speed $6000 \mathrm{rpm}$.

Step 5: Formulated Ethosomes forms the cloudy homogenous liquid. The Ethosomes were stored at temperature $4^{\circ} \mathrm{C} \pm 0.5^{\circ} \mathrm{C}$ for further evaluation (Table 1) [3,7-9].

Preparation of gel:

Step 1: Ethosomes equivalent to $1 \%$ of Tramadol $\mathrm{HCl}$ is calculated.

*Corresponding author: Om Shelke, Faculty of Pharmacy, Pacific Academy of Higher Education and Research, Udaipur, Rajasthan, India, Tel: 919769420371 E-mail: om.shelke20@gmail.com

Received: August 03, 2018; Accepted: September 17, 2018; Published: Septembe 24, 2018

Citation: Shelke O, Kulkarni A (2018) Formulation, Development and Evaluation of Nano Ethosomal Gel of Tramadol Hydrochloride. J Nanomed Nanotechnol 9: 514. doi: 10.4172/2157-7439.1000514

Copyright: (c) 2018 Shelke O, et al. This is an open-access article distributed under the terms of the Creative Commons Attribution License, which permits unrestricted use, distribution, and reproduction in any medium, provided the original author and source are credited. 
Step 2: Dissolve Disodium EDTA under stirring in purified water. Carbopol 980 is added under stirring and allows hydrating under stirring for $60 \mathrm{~min}$.

Step 3: Ethosomes are dispersed in the hydrated Carbopol 980 slurry under stirring and stirring continued for $30 \mathrm{~min}$.

Step 4: $\mathrm{pH}$ of the formulation is adjusted to 4.30 to 4.70 , a thick gel is formed (Table 2) $[10,11]$.

\section{Evaluation of ethosomes:}

Vesicles shape: Shape and Size of ethosomes were measured by the digital motic microscope. Ethosomes are dispersed in Mineral oil. Ethosomes dispersion is placed on the glass slide and focused under 100x object lens. The image was snapped by digital motic microscope using three different fields [12-14]

Vesicles size: Formulated ethosomes were analyzed by Malvern Sizer for vesicle size. Ethosomes were dispersed in purified water and the dispersion was placed in a clear disposable zeta cell for 90 seconds. The reading was taken in triplicate.

Zeta potential: Zeta potential of ethosomes was measured using laser dropper anemometry using Zetasizer. Ethosomes were dispersed in purified water. The dispersion of ethosomes was placed in the electrophoretic cell where the potential of $150 \mathrm{mV}$ was established. The analysis is performed in triplicate.

Optical microscopy: The Ethosomes are diluted with Liquid paraffin oil and mounted on glass slides. The dispersion is fixed with cover slip on the glass slide. The Microscopic examination is conducted using Motic Digital Microscope under 40X object lens. The 500 particles were calculated from different field and mean and a median is calculated.

Drug entrapment efficacy: Entrapment efficacy of ethosomes

\begin{tabular}{|c|c|c|c|c|c|}
\hline \multirow{2}{*}{$\begin{array}{c}\text { Formulation } \\
\text { Code }\end{array}$} & \multicolumn{5}{|c}{ Concentration of individual Ingredients } \\
\cline { 2 - 6 } & $\begin{array}{c}\text { Soya lecithin } \\
\text { (\%) }\end{array}$ & $\begin{array}{c}\text { Cholesterol } \\
\mathbf{( \% )}\end{array}$ & $\begin{array}{c}\text { Ethanol } \\
\mathbf{( \% )}\end{array}$ & $\begin{array}{c}\text { Drug } \\
\mathbf{( \% )}\end{array}$ & $\begin{array}{c}\text { Water } \\
\mathbf{( \% )}\end{array}$ \\
\hline FS 01 & 0.5 & - & 50 & 0.5 & 49 \\
\hline FS 02 & 0.6 & - & 50 & 0.5 & 48.9 \\
\hline FS 03 & 0.8 & - & 50 & 0.5 & 48.7 \\
\hline FS 04 & 1 & - & 50 & 0.5 & 48.5 \\
\hline FS 05 & 0.8 & - & 60 & 0.5 & 38.7 \\
\hline FS 06 & 1 & - & 60 & 0.5 & 38.5 \\
\hline FSC 01 & 0.6 & 0.2 & 60 & 0.5 & 38.75 \\
\hline FC 01 & - & 0.3 & 50 & 0.5 & 49.4 \\
\hline FC 02 & - & 0.4 & 50 & 0.5 & 49.35 \\
\hline FC 03 & - & 0.5 & 50 & 0.5 & 49.3 \\
\hline FC 04 & - & 0.6 & 50 & 0.5 & 49.25 \\
\hline FC 05 & - & 0.5 & 60 & 0.5 & 39.2 \\
\hline FC 06 & - & 0.6 & 60 & 0.5 & 39.1 \\
\hline
\end{tabular}

Table 1: Formulation Composition for Ethosomes. was performed by Ultra-centrifugation method. The indirect method is used to determine entrapment efficiency by measuring the unentrapped drug. The ethosomes have subjected the dispersion for ultracentrifugation (Remi) at $24000 \mathrm{rpm}$ for $60 \mathrm{~min}$. The clear supernatant layer is removed. The supernatant layer and sediment were analyzed for Tramadol $\mathrm{HCl}$ content by UV Spectrophotometer at 271 $\mathrm{nm}$. Each sample was prepared in duplicate $[15,16]$.

Entrapment Efficiency $(\%)=\frac{\text { Amount of drug in sediment }}{\text { Total amount of drug in supernatant and sediment }} \times 100$

In-vitro drug release for ethosomes: Ethosomes were spread on egg membrane equivalent amount $100 \mathrm{mg}$ of drug uniformly. This egg membrane is mounted on the donor compartment of Franz diffusion cell. The receptor compartment is filled with $24 \mathrm{ml}$ of $\mathrm{pH} 7.4$ Phosphate buffer. $1 \mathrm{ml}$ Samples are withdrawn at specific time points $15 \mathrm{~min}, 30$ min, 1 hr, 2 hr, 3 hr, 4 hr, 5 hr, 6 hr, 8 hr, $10 \mathrm{hr}$ and $12 \mathrm{hr}$. To maintain the sink condition at each time point replaces the withdrawn sample amount with fresh buffer solution. The study is carried out for $12 \mathrm{~h}$ [17-19].

\section{Evaluation of gel:}

Drug content: Gel formulations were evaluated for drug content (assay). The drug is extracted from the gel in the solvent mixture of methanol and water under sonication. The sample was analyzed by UV -spectrophotometer [20,21].

$p H: \mathrm{pH}$ of the formulation is determined by using direct method. $10 \mathrm{~g}$ of the sample was taken in glass vial and electrode is dipped in sample bulk. The stable readings were noted $[22,23]$.

Viscosity: Viscosity is determined using a Brookfield Cone and Plate Viscometer Model Cap 2000+. Sample approximately $100 \mathrm{mg}$ was kept on the plate and set method of $100 \mathrm{rpm}$ for $1 \mathrm{~min}$ is run [24,25].

Spreadability: The spreadability study was performed using a Brookfield Texture Analyzer. The sample is filled in the female cone and spread properly. Run the test at set parameters $[25,26]$.

In-vitro drug release: Gel formulation was spread on egg membrane equivalent amount $100 \mathrm{mg}$ drug uniformly. This egg membrane is mounted on the donor compartment of Franz diffusion cell. The receptor compartment is filled with $24 \mathrm{ml}$ of $\mathrm{pH} 7.4$ Phosphate buffer. $1 \mathrm{ml}$ Samples are withdrawn at specific time points $15 \mathrm{~min}, 30 \mathrm{~min}, 1$ $\mathrm{hr}, 2 \mathrm{hr}, 3 \mathrm{hr}, 4 \mathrm{hr}, 5 \mathrm{hr}, 6 \mathrm{hr}, 8 \mathrm{hr}, 10 \mathrm{hr}$ and $12 \mathrm{hr}$. To maintain the sink condition at each time point replaces the withdrawn sample amount with fresh buffer solution. The study is carried out for $12 \mathrm{hrs}[27,28]$.

Ex-vivo drug release: Based on the viscosity, spreadability, consistency and stability data of all the formulation, formulation FS05 $\mathrm{C} 03$ and FC05 C03 were selected for the ex-vivo drug release studies. Freshly excised ear skin of Porcine was soaked in pH 7.4 Buffer for $12 \mathrm{hr}$. Gel formulation was spread on skin equivalent amount $100 \mathrm{mg}$ drug uniformly. This skin is mounted on the donor compartment of

\begin{tabular}{|c|c|c|c|c|c|c|c|c|}
\hline \multirow{2}{*}{ Ingredients } & \multicolumn{8}{|c|}{ Formulation Code } \\
\hline & FS05 C01 & FS05 C02 & FS05 C03 & FS05 C04 & FC05 C01 & FC05 C02 & FC05 C03 & FC05 C04 \\
\hline Ethosomes Equivalent 1\% & 1.25 & 1.25 & 1.25 & 1.25 & 1.25 & 1.25 & 1.25 & 1.25 \\
\hline Disodium EDTA & 0.10 & 0.10 & 0.10 & 0.10 & 0.10 & 0.10 & 0.10 & 0.10 \\
\hline Carbopol 980 & 0.75 & 1.00 & 1.25 & 1.50 & 0.75 & 1.00 & 1.25 & 1.50 \\
\hline Triethanolamine & \multicolumn{8}{|c|}{ QS to adjust $\mathrm{pH} 4.40$ to 4.60} \\
\hline Purified Water & QS to 100 & QS to 100 & QS to 100 & QS to 100 & QS to 100 & QS to 100 & QS to 100 & QS to 100 \\
\hline
\end{tabular}

Table 2: Formulation Composition for gel formulation. 
Citation: Shelke O, Kulkarni A (2018) Formulation, Development and Evaluation of Nano Ethosomal Gel of Tramadol Hydrochloride. J Nanomed Nanotechnol 9: 514. doi: 10.4172/2157-7439.1000514

Page 3 of 6

Franz diffusion cell. The receptor compartment is filled with $24 \mathrm{ml}$ of pH 7.4 Phosphate buffer. $1 \mathrm{ml}$ Samples are withdrawn at specific time points $15 \mathrm{~min}, 30 \mathrm{~min}, 1 \mathrm{hr}, 2 \mathrm{hr}, 3 \mathrm{hr}, 4 \mathrm{hr}, 5 \mathrm{hr}, 6 \mathrm{hr}, 8 \mathrm{hr}, 10 \mathrm{hr}, 12$ $\mathrm{hr}, 16 \mathrm{hr}$ and $24 \mathrm{hr}$. To maintain the sink condition at each time point replaces the withdrawn sample amount with fresh buffer solution. The study is carried out for $24 \mathrm{hrs}$. Each sample solutions were prepared in duplicate [29-33].

Stability study: The stability study was conducted in the storage condition $40^{\circ} \mathrm{C} \pm 2{ }^{\circ} \mathrm{C} / 75 \% \pm 5 \% \mathrm{RH}$ and $25^{\circ} \mathrm{C} \pm 2{ }^{\circ} \mathrm{C} / 60 \% \pm 5 \% \mathrm{RH}$ for 3 Months. The stability samples were evaluated for description, $\mathrm{pH}$, Viscosity, drug content and in-vitro drug release [34-36].

\section{Results and Discussion}

\section{Vesicles shape}

All the formulation has shown the spherical shape of ethosomes. Results are tabulated in Table 3.

\section{Vesicles size}

Vesicles sizes of the formulated ethosomes are in the range of 939 $\eta \mathrm{m}$ to $1012 \mathrm{~nm}$. Results are tabulated in Table 3. All the formulations show vesicles sizes in the nano range. Nano ethosomes can be formulated with this composition.

\section{Zeta potential}

Zeta Potential of the formulation was found in the range -40 to -53 $\mathrm{mV}$. Results are tabulated in Table 3.

\section{Optical microscopy}

All the Ethosomes sizes are found in mean globule sized $0.94 \mu \mathrm{m}$ to $0.99 \mu \mathrm{m}$ through optical microscopy. Results are tabulated in Table 3 . All ethosomes are in spherical in nature.

\section{Drug entrapment efficiency}

Drug Entrapment efficiency was measured by both the Direct and indirect method. Both the method has shown approximately similar results. T Results are tabulated in Table 4 . The highest entrapment efficiency found with FS 04, FS 05, FS 06, FC 04, FC 05 and FC 06. The concentration of Soya lecithin in $0.8 \%$ to $1 \%$ and Cholesterol $0.5 \%$ to $0.6 \%$ has the highest drug entrapment efficiency.

\begin{tabular}{|c|c|c|c|c|}
\hline $\begin{array}{c}\text { Formulation } \\
\text { Code }\end{array}$ & Vesicle Shape & $\begin{array}{c}\text { Vesicle Size } \\
\mathbf{( n m})\end{array}$ & $\begin{array}{c}\text { Zeta Potential } \\
\mathbf{( m V} \mathbf{)}\end{array}$ & $\begin{array}{c}\text { Optical } \\
\text { Microscopy }\end{array}$ \\
\hline FS 01 & Spherical & 975 & -47.62 & 0.95 \\
\hline FS 02 & Spherical & 963 & -45.12 & 0.97 \\
\hline FS 03 & Spherical & 971 & -52.64 & 0.95 \\
\hline FS 04 & Spherical & 981 & -42.17 & 0.97 \\
\hline FS 05 & Spherical & 991 & -40.49 & 0.99 \\
\hline FS 06 & Spherical & 952 & -46.45 & 0.96 \\
\hline FSC 01 & Spherical & 1012 & -43.16 & 0.98 \\
\hline FC 01 & Spherical & 974 & -45.91 & 0.95 \\
\hline FC 02 & Spherical & 962 & -50.45 & 0.95 \\
\hline FC 03 & Spherical & 943 & -51.98 & 0.96 \\
\hline FC 04 & Spherical & 939 & -53.01 & 0.94 \\
\hline FC 05 & Spherical & 981 & -49.81 & 0.98 \\
\hline FC 06 & Spherical & 974 & -49.34 & 0.97 \\
\hline
\end{tabular}

$\mathrm{n}$ : all the readings are executed in triplicate and average of three reading were recorded

Table 3: Vesicles Shape, size, Zetapotential and Optical Microscopy data.

\begin{tabular}{|c|c|c|}
\hline \multirow{2}{*}{ Formulation Code } & \multicolumn{2}{|c|}{ Entrapment Efficiency } \\
\cline { 2 - 3 } & Direct method & Indirect Method \\
\hline FS 01 & 65.34 & 67.45 \\
\hline FS 02 & 68.93 & 70.13 \\
\hline FS 03 & 75.12 & 76.98 \\
\hline FS 04 & 78.23 & 79.34 \\
\hline FS 05 & 79.9 & 80.45 \\
\hline FS 06 & 80.57 & 81.67 \\
\hline FSC 01 & 73.94 & 75.39 \\
\hline FC 01 & 60.12 & 62.17 \\
\hline FC 02 & 61.89 & 64.01 \\
\hline FC 03 & 69.26 & 72.28 \\
\hline FC 04 & 78.51 & 80.48 \\
\hline FC 05 & 79.72 & 80.91 \\
\hline FC 06 & 80.69 & 82.51 \\
\hline
\end{tabular}

Table 4: Drug Entrapment Efficiency in Ethosomes.

\section{In-vitro drug release for ethosomes}

The highest drug release found with FS 05 (85.75\%) and FC 05 $(86.17 \%)$. Results are tabulated in Table 5 and graphically represented in Figures 1 and 2. The lower concentration of soya lecithin and cholesterol has initial faster drug release but after 4 hours, they have shown slower drug release. Higher levels of alcohols in the formulation have better drug release if the concentration of either soya lecithin or cholesterol is constant.

Initial drug release for batches FC 04 and FS 03 is higher up to 5 $\mathrm{hr}$ and then drug release is lower compared to other formulation. But drug release for batch FC 05 and FS 05 is initially low till $5 \mathrm{hr}$ and after that the drug release is constant.

\section{Evaluation of gel}

Drug content: Assay (\% drug content) is found in the range $96.2 \%$ to $99.3 \%$. Results are tabulated in Table 6 . Assay (\% drug content) of all the formulations is in an acceptable range.

pH: $\mathrm{pH}$ of all the formulation was found in the range 4.49 to 4.58 . Results are tabulated in Table 6. All the $\mathrm{pH}$ range is acceptable for formulation.

Viscosity: The viscosity of all formulation is in the range of 1.76 to $2.83 \mathrm{cPs}$. Results are tabulated in Table 6 . The increase in the concentration of the polymer, the viscosity of the formulation increases. All the formulations have shown polymer concentration-dependent viscosity. The viscosity of the formulation may affect the drug release from the formulation.

Spreadability: Spreadability of the formulation is found in the range 10.78 to 14.94 . Results are tabulated in Table 6. Spreadability of the formulation is inversely proportional to the viscosity of the formulation. The increase in the concentration of Polymer the spreadability decreases.

In-vitro drug release: Amount of drug release from all the gel formulation was found in the range of 70-83\%. Maximum drug release found with formulation $83.45 \%$ with soya lecithin formulation and $84.45 \%$ with Cholesterol formulation. Results are tabulated in Table 7 and graphically represented in Figures 3 and 4 . The concentration of Polymer in the formulation has a significant impact on the invitro drug release from the formulation. The increase in the polymer concentration in the formulation, drug release from formulation 
Citation: Shelke O, Kulkarni A (2018) Formulation, Development and Evaluation of Nano Ethosomal Gel of Tramadol Hydrochloride. J Nanomed Nanotechnol 9: 514. doi: 10.4172/2157-7439.1000514

Page 4 of 6

decreases. The drug release from the formulation decreases with an increase in polymer concentration, this may be due to increase in viscosity of the formulation with the increase in polymer concentration.

FC05 C01 has higher drug release when compared with other formulation this may be due to lower concentration of polymer in formulation. Formulation with same polymer concentration but with different composition of Ethosomes has different drug release pattern. Higher concentration of polymer retards the drug release due to high viscosity; May high viscosity of formulation retards the drug diffusion.

Ex-vivo drug release: Ex-vivo release and in-vitro drug for both the formulation is almost similar. The results are tabulated in Table 7 and graphically represented in Figures 5 and 6 . In 24 h the ex-vivo drug release from formulation FS05 C03 is $85.45 \%$ and $\mathrm{FC} 05 \mathrm{C0} 3$ is $81.98 \%$. Both the formulation has shown similar drug release pattern. The formulation FS05 $\mathrm{C} 03$ has better drug release than the formulation FC05 C03.

\section{Formulation}

Stability study: Formulations FC05 C03 and FS05 C03 have shown good stability for $3 \mathrm{M}$ stability study at temperature condition $40^{\circ} \mathrm{C} \pm 2^{\circ} \mathrm{C} / 75 \% \pm 5 \% \mathrm{RH}$ and $25^{\circ} \mathrm{C} \pm 2{ }^{\circ} \mathrm{C} / 60 \% \pm 5 \% \mathrm{RH}$. All the Physicochemical stability results were tabulated in Table 8 . The in-vitro drug release of $3 \mathrm{M}$ sample is tabulated in Table 9. Both the formulations are physically and chemically stable for 3 Months at Room temperature and accelerated storage conditions.

\begin{tabular}{|c|c|c|c|c|c|c|c|}
\hline \multirow{2}{*}{ Time } & \multicolumn{7}{|c|}{ Formulation Code } \\
\hline & FS 03 & FS 04 & FS 05 & FS 06 & FC 04 & FC 05 & FC 06 \\
\hline & \multicolumn{7}{|c|}{ nulative amount of Drug Diffused } \\
\hline 0 & 0 & 0 & 0 & 0 & 0 & 0 & 0 \\
\hline $15 \mathrm{~min}$ & 12.29 & 7.12 & 5.23 & 3.99 & 10.23 & 6.45 & 5.34 \\
\hline $30 \mathrm{~min}$ & 20.93 & 12.94 & 12.34 & 10.34 & 18.23 & 11.45 & 9.98 \\
\hline $1 \mathrm{Hr}$ & 30.34 & 20.45 & 18.52 & 16.23 & 26.67 & 19.93 & 15.28 \\
\hline $2 \mathrm{Hr}$ & 40.91 & 28.34 & 27.91 & 25.49 & 39.34 & 25.67 & 24.95 \\
\hline $3 \mathrm{Hr}$ & 52.34 & 45.42 & 38.56 & 36.71 & 47.23 & 36.78 & 33.67 \\
\hline $4 \mathrm{Hr}$ & 60.12 & 60.12 & 46.23 & 42.38 & 56.24 & 48.92 & 44.38 \\
\hline $5 \mathrm{Hr}$ & 62.45 & 60.89 & 58.91 & 50.23 & 63.45 & 59.67 & 48.79 \\
\hline $6 \mathrm{Hr}$ & 63.51 & 61.19 & 71.25 & 58.12 & 67.41 & 72.37 & 60.38 \\
\hline $8 \mathrm{Hr}$ & 64.32 & 61.32 & 75.18 & 65.23 & 68.12 & 76.23 & 64.56 \\
\hline $10 \mathrm{Hr}$ & 64.78 & 61.78 & 80.31 & 68.27 & 68.92 & 81.87 & 69.81 \\
\hline $12 \mathrm{Hr}$ & 65.13 & 62.13 & 85.75 & 71.3 & 70.19 & 86.17 & 74.89 \\
\hline
\end{tabular}

$\mathrm{n}$ : Diffusion study is carried out in duplicate and average reading were recorded.

Table 5: In-vitro drug release study data for ethosomes.

In-vitro Drug Release From Ethosomes

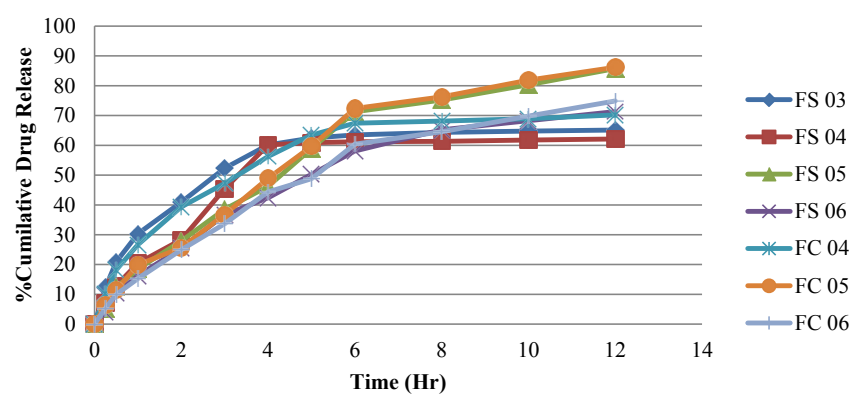

Figure 1: In-vitro drug release from Ethosomes.

\begin{tabular}{|c|c|c|c|c|}
\hline $\begin{array}{c}\text { Formulation } \\
\text { Code }\end{array}$ & $\begin{array}{c}\text { \% Drug } \\
\text { Content }\end{array}$ & pH & $\begin{array}{c}\text { Viscosity } \\
\text { cPs }\end{array}$ & Spread-ability \\
\hline FS05 C01 & 99.1 & 4.55 & 1.76 & 10.78 \\
\hline FS05 C02 & 98.0 & 4.54 & 2.12 & 11.24 \\
\hline FS05 C03 & 99.2 & 4.51 & 2.45 & 12.56 \\
\hline FS05 C04 & 98.8 & 4.56 & 2.78 & 14.35 \\
\hline FC05 C01 & 98.3 & 4.58 & 1.80 & 11.11 \\
\hline FC05 C02 & 99.3 & 4.57 & 2.23 & 12.23 \\
\hline FC05 C03 & 97.1 & 4.51 & 2.36 & 13.08 \\
\hline FC05 C04 & 96.2 & 4.49 & 2.83 & 14.94 \\
\hline
\end{tabular}

Table 6: Drug content, $\mathrm{pH}$, viscosity and Spreadability data.

\begin{tabular}{|c|c|c|c|c|c|c|c|c|}
\hline \multirow{3}{*}{ Time } & \multicolumn{8}{|c|}{ Formulation Code } \\
\hline & $\begin{array}{c}\text { FS05 } \\
\text { C01 }\end{array}$ & $\begin{array}{c}\text { FS05 } \\
\text { C02 }\end{array}$ & $\begin{array}{c}\text { FS05 } \\
\text { C03 }\end{array}$ & $\begin{array}{c}\text { FS05 } \\
\text { C04 }\end{array}$ & $\begin{array}{c}\text { FC05 } \\
\text { C01 }\end{array}$ & $\begin{array}{c}\mathrm{FC} 05 \\
\mathrm{C} 02\end{array}$ & $\begin{array}{c}\mathrm{FC} 05 \\
\mathrm{C03}\end{array}$ & $\begin{array}{c}\mathrm{FC} 05 \\
\mathrm{C04}\end{array}$ \\
\hline & \multicolumn{8}{|c|}{$\%$ Cumulative Amount of Drug Diffused } \\
\hline 0 & 0 & 0 & 0 & 0 & 0 & 0 & 0 & 0 \\
\hline $15 \mathrm{~min}$ & 5.23 & 5.12 & 4.56 & 3.45 & 6.25 & 5.89 & 5.34 & 4.18 \\
\hline $30 \mathrm{~min}$ & 10.44 & 10.14 & 10.45 & 9.78 & 11.23 & 10.14 & 9.56 & 8.38 \\
\hline $1 \mathrm{hr}$ & 16.61 & 15.98 & 16.01 & 16.45 & 18.45 & 17.78 & 16.49 & 14.89 \\
\hline $2 \mathrm{hr}$ & 25.48 & 24 & 2 & 2 & 2 & 22.31 & 21.65 & 20.98 \\
\hline $3 \mathrm{hr}$ & 36.56 & 35.64 & 34.87 & 32.84 & 35.78 & 33.45 & 31.73 & 30.06 \\
\hline $4 \mathrm{hr}$ & 45.02 & 46.23 & 44.23 & 41.67 & 46.38 & 44.98 & 43.16 & 41.84 \\
\hline $5 \mathrm{hr}$ & 56.78 & 55.19 & 56.76 & 51.98 & 57.88 & 53.91 & 52.38 & 50.37 \\
\hline $6 \mathrm{hr}$ & 68.56 & 65.49 & 63.47 & 58.45 & 71.09 & 63.56 & 61.92 & 60.25 \\
\hline $8 \mathrm{hr}$ & 74.12 & 71.82 & 68.45 & 63.46 & 74.56 & 69.92 & 68.35 & 66.15 \\
\hline $10 \mathrm{hr}$ & 78.34 & 76.98 & 74.34 & 66.78 & 79.78 & 78.16 & 76.45 & 73.49 \\
\hline $12 \mathrm{hr}$ & 83.45 & 82.34 & 79.91 & 70.33 & 84.45 & 82.89 & 81.02 & 78.26 \\
\hline
\end{tabular}

Table 7: In-vitro drug release study data for ethosomes.

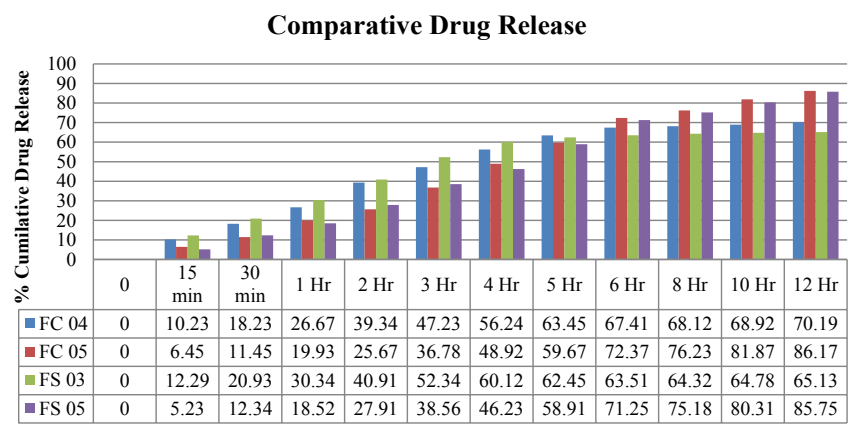

Figure 2: Comparative drug release from ethosomes.

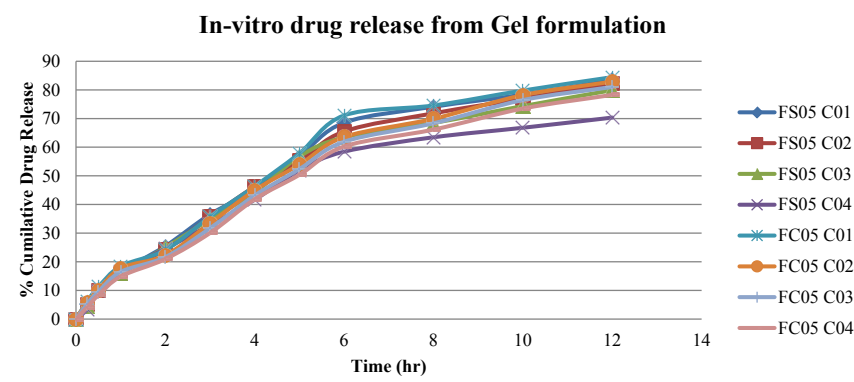

Figure 3: In-vitro drug release from Gel formulation. 
Citation: Shelke O, Kulkarni A (2018) Formulation, Development and Evaluation of Nano Ethosomal Gel of Tramadol Hydrochloride. J Nanomed Nanotechnol 9: 514. doi: 10.4172/2157-7439.1000514

Page 5 of 6

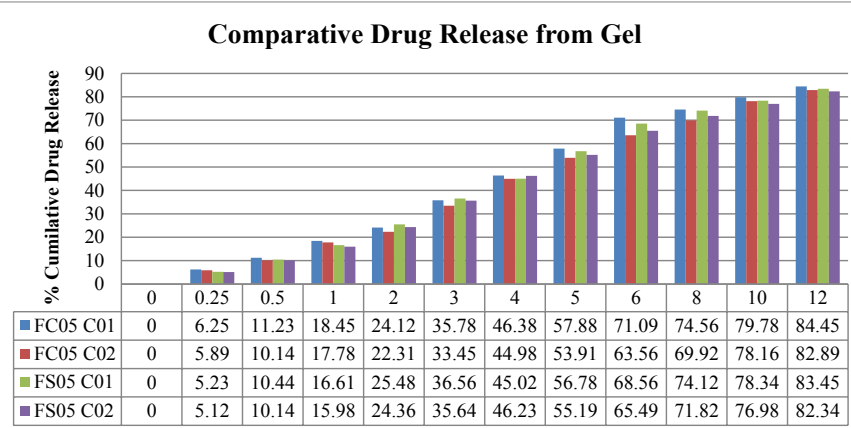

Figure 4: Comparative Drug Release from Gel.

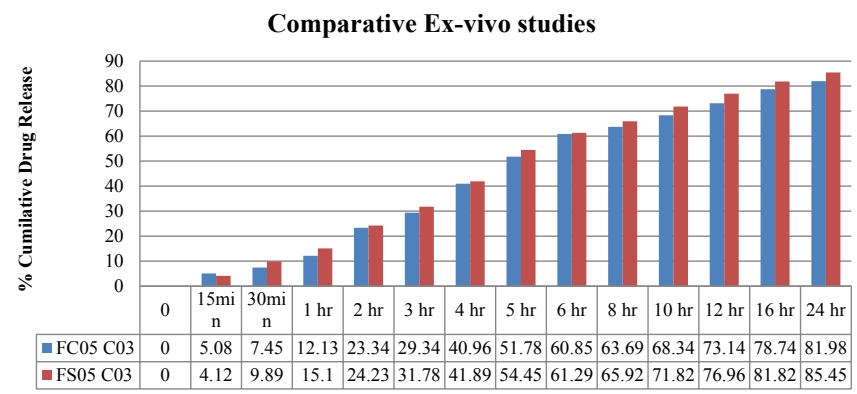

Figure 5: Ex-Vivo drug release study.

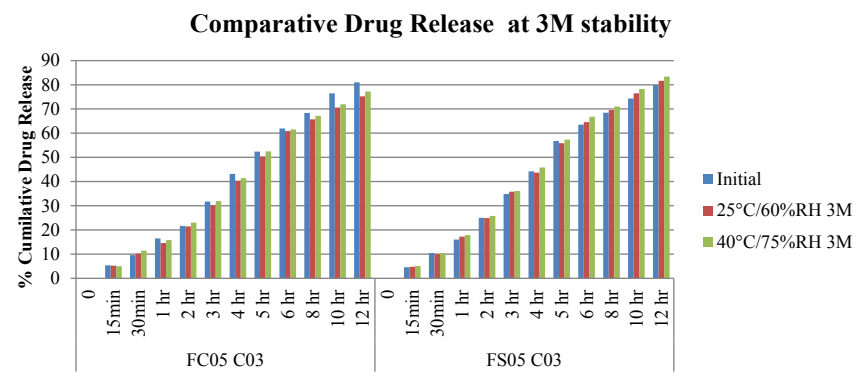

Figure 6: IVRT Study of 3M Stability Samples.

\begin{tabular}{|c|c|c|c|c|c|}
\hline $\begin{array}{l}\text { Formulation } \\
\text { Code }\end{array}$ & Condition & $\begin{array}{l}\text { Time } \\
\text { Point }\end{array}$ & $\mathrm{pH}$ & Viscosity & $\begin{array}{l}\% \text { Drug } \\
\text { Content }\end{array}$ \\
\hline \multirow{6}{*}{ FC05 C03 } & \multirow{3}{*}{$40^{\circ} \mathrm{C} / 75 \% \mathrm{RH}$} & $1 \mathrm{M}$ & 4.53 & 2.53 & 99.1 \\
\hline & & $2 \mathrm{M}$ & 4.48 & 2.42 & 98.6 \\
\hline & & $3 \mathrm{M}$ & 4.45 & 2.32 & 97.9 \\
\hline & \multirow{3}{*}{$25^{\circ} \mathrm{C} / 60 \% \mathrm{RH}$} & $1 \mathrm{M}$ & 4.55 & 2.52 & 99.8 \\
\hline & & $2 \mathrm{M}$ & 4.49 & 2.43 & 99.4 \\
\hline & & $3 \mathrm{M}$ & 4.45 & 2.35 & 98.9 \\
\hline \multirow{6}{*}{ FS05 C03 } & \multirow{3}{*}{$40^{\circ} \mathrm{C} / 75 \% \mathrm{RH}$} & $1 \mathrm{M}$ & 4.57 & 2.51 & 99.7 \\
\hline & & $2 \mathrm{M}$ & 4.52 & 2.45 & 99.2 \\
\hline & & $3 \mathrm{M}$ & 4.46 & 2.34 & 98.4 \\
\hline & \multirow{3}{*}{$25^{\circ} \mathrm{C} / 60 \% \mathrm{RH}$} & $1 \mathrm{M}$ & 4.52 & 2.47 & 99.8 \\
\hline & & $2 \mathrm{M}$ & 4.55 & 2.52 & 99.5 \\
\hline & & $3 \mathrm{M}$ & 4.52 & 2.46 & 98.7 \\
\hline
\end{tabular}

Table 8: Results for the Physicochemical test for $3 \mathrm{M}$ Stability Study Sample.

Drug release from the formulation FS05 $\mathrm{C} 03$ has comparable with the initial sample while in case of formulation FC05 C03 the drug has been dropped significantly. The drug release profile at accelerated storage condition is slightly higher when compared to room temperature sample. This may be due to slight drop in viscosity at

\begin{tabular}{|c|c|c|c|c|c|c|}
\hline \multirow{4}{*}{ Time } & \multicolumn{6}{|c|}{ Formulation Code } \\
\hline & \multicolumn{3}{|c|}{ FS05 C03 } & \multicolumn{3}{|c|}{ FC05 C03 } \\
\hline & Initial & $\begin{array}{c}3 \mathrm{M} \\
25^{\circ} \mathrm{C} / 60 \% \mathrm{RH}\end{array}$ & \begin{tabular}{c|}
$3 \mathrm{M}$ \\
$40^{\circ} \mathrm{C} / 75 \% \mathrm{RH}$
\end{tabular} & Initial & \begin{tabular}{c|c|}
$3 \mathrm{M}$ \\
$25^{\circ} \mathrm{C} / 60 \% \mathrm{RH}$
\end{tabular} & $\begin{array}{c}3 \mathrm{M} \\
40^{\circ} \mathrm{C} / 75 \% \mathrm{RH}\end{array}$ \\
\hline & \multicolumn{6}{|c|}{$\%$ Amount of Drug Released } \\
\hline 0 & 0 & 0 & 0 & 0 & 0 & 0 \\
\hline $15 \mathrm{~min}$ & 4.56 & 4.78 & 5.12 & 5.34 & 5.23 & 4.98 \\
\hline $30 \mathrm{~min}$ & 10.45 & 9.98 & 10.45 & 9.56 & 10.23 & 11.45 \\
\hline $1 \mathrm{hr}$ & 16.01 & 17.23 & 17.89 & 16.49 & 14.56 & 15.78 \\
\hline $2 \mathrm{hr}$ & 25.02 & 24.89 & 25.78 & 21.65 & 21.42 & 23.02 \\
\hline $3 \mathrm{hr}$ & 34.87 & 35.78 & 36.13 & 31.73 & 30.23 & 31.89 \\
\hline $4 \mathrm{hr}$ & 44.23 & 43.67 & 45.78 & 43.16 & 40.35 & 41.41 \\
\hline $5 \mathrm{hr}$ & 56.76 & 55.83 & 57.34 & 52.38 & 50.34 & 52.45 \\
\hline $6 \mathrm{hr}$ & 63.47 & 64.56 & 66.76 & 61.92 & 60.85 & 61.56 \\
\hline $8 \mathrm{hr}$ & 68.45 & 69.54 & 70.98 & 68.35 & 65.71 & 67.13 \\
\hline $10 \mathrm{hr}$ & 74.34 & 76.45 & 78.24 & 76.45 & 70.56 & 71.94 \\
\hline $12 \mathrm{hr}$ & 79.91 & 81.67 & 83.34 & 81.02 & 75.23 & 77.18 \\
\hline
\end{tabular}

Table 9: In-vitro drug release Results of 3M Stability Study Sample.

accelerated storage condition which is affecting the drug release profile. Viscosity of the formulation affects the drug release profiles may be due change in diffusion rate due to change mobility of drug molecules.

\section{Conclusion}

Ethosomes has more stability and penetration than the liposomes. The stable ethosomes can be formulated with using the composition soya lecithin, cholesterol, ethanol and water. The concentration of ethanol increases in the formulation of ethosomes, the stability and drug release from the formulation increases. Drug loaded Ethosomes are suitable to entrap in the gel matrix for suitable drug application. Stable Gel formulation is formulated with different concentration $(0.75 \%, 1.0 \%, 1.25 \%, 1.5 \% \mathrm{w} / \mathrm{w})$ of Carbopol 980. Ethosomes were evaluated for vehicle shape, size, zeta potential, and drug release and entrapment efficiency. The ethosome formulation FS05 $(0.8 \%$ Soya lecithin $60 \%$ ethanol) and FC05 (0.3\% Cholesterol and 60\% ethanol) have drug release profile amongst all the formulations. The Gel formulation FS05 C03 (1.25\% Carbopol) and FC05 C03 (1.25\% Carbopol) has better in-vitro drug release profile amongst all the formulation. The increase in the concentration of Carbopol 980 has the direct impact on the viscosity and drug release profile. The increase in Carbopol 980 concentration viscosity of the formulation increases and decreases the drug release from the formulation. The ex-vivo study has shown a similar release pattern to the in-vitro release study from both the formulation FS05 and FC05. Both the formulations were stable for 3 $\mathrm{M}$ at room temperature and accelerated temperature storage condition. Formulation FS05 $\mathrm{C} 03$ has shown similar drug release pattern to the initial sample while formulation FC05 C03 has shown a significant drop in drug release from the formulation. Samples at accelerated storage condition have shown slightly higher drug release than room temperature.

\section{References}

1. Venugopal V, Goh R, Ping TY, Jin TJ (2015) Formulation Development and Characterization of Tea Tree Oil Loaded Ethosomes. Indo Nesian J Pharm 27: 44-52.

2. Reanmongkol W, Kaewnopparat N, Ratanajamit C (2011) Physicochemica properties, in vitro release and in vivo evaluation of tramadol hydrochloride rectal suppository and rectal gel. Asian Biomedicine 5: 269-275.

3. Bhalaria MK, Naik S, Misra AN (2009) Ethosomes: A novel delivery system for antifungal drugs in the treatment of topical fungal diseases. Indian J Exp Biol 47: $368-375$. 
Citation: Shelke O, Kulkarni A (2018) Formulation, Development and Evaluation of Nano Ethosomal Gel of Tramadol Hydrochloride. J Nanomed Nanotechnol 9: 514. doi: 10.4172/2157-7439.1000514

Page 6 of 6

4. Touitou E, Dayan N, Bergelson L, Godin B, Eliaz M (2000) Ethosomes-nove vesicular carriers for enhanced delivery: characterization and skin penetration properties. J Control Release 65: 403-418.

5. Belgamwar VS, Patel HS, Joshi AS, Surana SJ, Tekade AR (2011) Design and development of nasal mucoadhesive microspheres containing tramadol $\mathrm{HCl}$ for CNS targeting. Drug Deliv 18: 353-360.

6. Saleem MA, Taher M, Najmuddin M, Ali J, Humaira S, et al. (2008) Formulation and Evaluation of Tramadol hydrochloride Rectal Suppositories. Indian J Pharm Sci 70: 640-644.

7. Mistry A, Ravikumar P (2016) Development and Evaluation of Azelaic Acid Based Ethosomes for Topical Delivery for the Treatment of Acne. IJPER 50: S232-S243.

8. Limsuwan T, Amnuaikit T (2012) Development of Ethosomes Containing Mycophenolic Acid. Procedia Chemistry 4: 328-335.

9. Maurya SD, Prajapati SK, Gupta AK, Saxena GK, Dhakar RC (2010) Formulation Development and Evaluation of Ethosome of Stavudine. IJPER 44: 102-108.

10. Chintala PK, Padmapreetha J (2014) Formulation and In-Vitro Evaluation of Gel Containing Ethosomes Entrapped With Etodolac. Int J Pharm Sci Res 5: 630-635.

11. Supraja R, Sailaja AK (2017) Formulation of Mefenamic Acid Loaded Ethosoma Gel by Hot and Cold Methods. Nano Biomedical Engineering 9: 27-35.

12. Shaik RA, Sadhana C, Pragati S, Komati RP, Pavani B (2016) Formulation and In-Vitro Evaluation of Aceclofenac Ethosomes. Indo Amr J Pharm 2: 35-41.

13. Chan SY, Chourasia MK, Kang L (2011) Nanosized ethosomes bearing ketoprofen for improvedtransdermal delivery. Results Pharma Sci 1: 60-67.

14. Ramteke S, Barupal AK, Gupta V (2010) Preparation and Characterization of Ethosomes for Topical delivery of Aceclofenac. Indian J Pharm Sci 72: 582 586

15. Rathore AR, Khambete H, Jain S (2013) Preparation and Characterization of Repaglinide Loaded Ethosomal Gel for the Treatment of NIDDM. Int J Pharma Bio Arc 4: 385-390.

16. Jain S, Patel N, Madan P, Lin S (2015) Quality by design approach for formulation, evaluation and statistical optimization of diclofenac-loaded ethosomes via transdermal route. Pharm Dev Technol 20: 473-489.

17. Reddy AS, Rao MS, Ashok KA (2016) Preparation and Evaluation of Simvastatin Ethosomes. Indo Am J Pharmac Sci 3: 175-186.

18. Rakesh R, Anoop KR (2012) Formulation and optimization of nano-sized ethosomes for enhanced transdermal delivery of cromolyn sodium. J Pharm Bioallied Sci 4: 333-340.

19. Paradkar MU, Patel J (2018) Formulation Development and Evaluation of Transdermal 5- Fluorouracil Ethosomal Formulation for the Treatment of Non-Melanoma Skin Cancer through 25-2 Fractional Factorial Design. Drug Delivery Letter 8: 1.

20. Zeeshan F, Nimisha, Kaur CD (2017) Formulation and Performance Evaluation of Berberis Aristata Extract Loaded Ethosomal Gel. Asian J Pharma 11: 176183
21. Kumar KK, Nandini N, Sudhakar M, Sujatha S, Prakash US (2014) Design, development and characterization of ethosomal gel of Naproxen. Pharmaceut Anal Acta 5: 124

22. Garg BJ, Garg NK, Beg S, Singh B, Katare OP (2016) Nanosized ethosomesbased hydrogel formulations of methoxsalen for enhanced topical delivery against vitiligo: formulation optimization, in vitro evaluation and preclinical assessment. J Drug Target 24: 233-246.

23. Sowjanya S, Shivanand K, Divakar G, Tejaswi G, Venkatanagaraju E, et al. (2013) Development And Invitro Evaluation Of Gel Containig Ethosomes Entrapped With Sulfasalazine. World J Pharmacy and Pharmac Sci 2: 66296639

24. Akhtar N, Pathak K (2012) Cavamax W7 Composite Ethosomal Gel of Clotrimazole for Improved Topical Delivery: Development and Comparison with Ethosomal Gel. AAPS Pharm Sci Tech 13: 344-355.

25. Verma P, Pathak K (2012) Nanosized ethanolic vesicles loaded with econazole nitrate for the treatment of deep fungal infections through topical gel formulation. Nanomedicine 8: 489-496.

26. Pathak AA, Chaudhari PD (2012) Development and Evaluation of Nanogel as a Carrier for Transdermal Delivery of Aceclofenac. Asian J Pharm Tech 2: 125-132.

27. Srag El-din AS, El-menshawe SF, Ali AA, Halawa AA (2017) A nove transdermal nanoethosomal gel of betahistine dihydrochloride for weight gain control: in-vitro and invivo characterization. Drug Des Devel Ther 11: 3377 3388.

28. Johny NK, Krishna K, Dinesh KB, Nair SK (2017) Ethosomal Gel: A Review. Euro J Pharma Med Res 4: 301-305.

29. Sundari BT, Rao PS, Sireesha K, Sai YK (2017) Formulation And Evaluation Of Ethosomal Gels of Mangifera Indica Leaf Extract. Indo Amer J Pharma Sc 4: 1755-1761.

30. Ramadon D, Wirarti GA, Effionora A (2017) Novel Transdermal Ethosoma Gel Containing Green Tea (Camellia sinensis L. Kuntze) Leaves Extract: Formulation and In vitro Penetration Study. J Young Pharmacists 9: 336-340.

31. Ramadon D, Effionora A, Harahap Y (2017) In vitro Penetration and Bioavailability of Novel Transdermal Quercetin-loaded Ethosomal Gel. Ind J Pharma Sci 79: 948-956.

32. Elmenshawe SF, Kharshoum RM, El-sisi AM (2017) Preparation and Optimization of Buccal Propranolol Hydrochloride Nanoethosomal Gel: A Nove Approach for Enhancement of Bioavailability. J Nanomed Nanotech 8: 01-09.

33. Verma P, Pathak K (2010) Therapeutic and cosmeceutical potential of ethosomes: An overview. J Advanced Pharmaceutical Tech \& Res 1: 274-282.

34. Guidlines ICH (2003) Stability testing of new drug substances and products Q1A (R2). International conference on harmonization of technical requirements for registration of pharmaceuticals for human use. 4: 1-24.

35. Guidlines USFDA (2003) Guidance for Industry Q1A (R2) Stability Testing of New Drug Substances and Products. United sate Food and drug administration 2: 1-22.

36. Guidlines EMEA (2003) Q1 A (R2) Stability Testing of new Drug Substances and Products. Eur Medicines Agency 2736: 1-20. 